\title{
Dynamics of human-induced lakes and their impact on land surface temperature in Toshka Depression, Western Desert, Egypt
}

Rasha Abou Samra ( $\square$ rasha.mohamed67@yahoo.com )

Damietta University https://orcid.org/0000-0001-5109-6733

\section{Research Article}

Keywords: Land surface temperature, Land use/land cover (LULC), Automated Water Extraction Index (AWEI), Toshka, GIS

Posted Date: February 16th, 2021

DOI: https://doi.org/10.21203/rs.3.rs-229433/v1

License: (c) (1) This work is licensed under a Creative Commons Attribution 4.0 International License.

Read Full License 


\section{Title page}

2 Title: Dynamics of human-induced lakes and their impact on land surface temperature in Toshka Depression, Western

3 Desert, Egypt

4

$5 \quad$ Names of the authors: Rasha M. Abou Samra

6 Affiliations and addresses of the authors:

7 First author: Rasha M. Abou Samra - Lecturer of Environmental Sciences- Department of Environmental Sciences,

8 Faculty of Science, Damietta University, New Damietta, Egypt.

9 E-mail: rasha.mohamed67@yahoo.com

10 The full professional address, e-mail address and telephone number of the corresponding author

11 Corresponding author: Rasha M. Abou Samra

12 Address: Environmental Sciences Department- Faculty of Science- Damietta University- Egypt

13 Tel.: +20 1090555316; fax: +20 57 2403868; Postal Code: 3451

14 Orchid ID: https://orcid.org/0000-0001-5109-6733

15

16

17

18

19

20

21

22

23

24

25

26

27

28

29 
Abstract

Land surface temperature (LST) is a significant environmental variable that is appreciably influenced by land use /land cover changes. The main goal of this research was to quantify the impacts of land use/land cover change (LULC) from the drying of Toshka Lakes on LST by remote sensing and GIS techniques. Landsat series TM and OLI satellite images were used to estimate LST from 2001 to 2019. Automated Water Extraction Index (AWEI) was applied to extract water bodies from the research area. Optimized Soil-Adjusted Vegetation Index (OSAVI) was utilized to predict the reclaimed land in the Toshka region until 2019. The results indicated a decrease in the lakes by about $1517.79 \mathrm{~km}^{2}$ with an average increase in LST by about $25.02^{\circ} \mathrm{C}$ between 2001 and 2019. It was observed that the dried areas of the lakes were converted to bare soil and are covered by salt crusts. The results indicated that the land use change was a significant driver for the increased LST. The mean annual LST increased considerably by $0.6^{\circ} \mathrm{C} / \mathrm{y}$ between 2001 and 2019. A strong negative correlation between LST and Toshka Lakes area (R-square $=0.98$ ) estimated from regression analysis implied that Toshka Lakes drying considerably affected the microclimate of the study area. Severe drought conditions, soil degradation, and many environmental issues were predicted due to the rise of LST in the research area. There is an urgent need to develop favorable strategies for sustainable environmental management in the Toshka region.

Keywords: Land surface temperature; Land use/land cover (LULC); Automated Water Extraction Index (AWEI); Toshka; GIS

\section{Introduction}

Land surface temperature (LST) is a significant environmental variable, and its mapping and analysis with other environmental parameters assume greater importance, especially in desert ecosystems. LST is a crucial variable in the weather pattern that controls the heat of the surface and water transfer in the interface between the atmosphere and the land (Yu and Yu, 2020). Recognizing land temperature changes over a certain period is one of the key requirements for assessing climate change (Orhan et al. 2014). There is an increasing problem that human-related changes in Earth's surface can affect climatic conditions locally or globally by altering their physical characteristics (Jingyong et al. 2005). Land use changes act as a pivotal factor in environmental resource management and conservation. Land Use/Land Cover (LULC) patterns have a crucial role in conserving the environment from exposure to direct solar radiation and increasing the surface temperature of the environment. Nevertheless, the type of LULC changes over time has caused rapid alterations in the environment and enhanced the deterioration of the environment (Balew and Korme 2020). Most land cover changes related to human activities are caused by land cover transformation, land

62 Due to the diversity in Earth's surface properties, the LST changes significantly. Therefore, continuous measurements 63 are required to distinguish temporal changes in the Earth's surface (Li et al. 2013). The statistics from meteorological 
cover (Zhou and Wang 2011). Remote sensing images are the only practical application for estimating LST on very large spatial and temporal scales when meteorological stations cannot provide Earth's temperature in large areas (Owen et al. 1998; Feizizadeh and Blaschke 2012; Li et al. 2013). LST can be derived from the thermal bands of remotely sensed images by many methods, depending on the utilized bands (Pu et al. 2006). Sinha et al. (2015) suggested a heat generation index using spectral data from remote sensing images to enhance the validity of LULC classification. They showed that, for regional investigation of LST, Landsat ETM+ is a preferable option. Mendelsohn et al. (2007) tested the climatic data obtained from satellites compared to ground estimates. They concluded that temperature detection from satellite images partially exceeds the capabilities of ground stations because of the capability of satellites in large-scale temperature monitoring. Hooker et al. (2018) investigated that remotely sensed temperature detection provides preferable results compared to the data acquired from meteorological stations.

The relationship between changes in LULC and LST dynamics has been the subject of several studies. Hereher (2017) used MODIS LST data to show changes in LST due to changes in LULC from 2003 to 2015 in the Toshka region of Egypt. Abd El-Hamid (2020) used Landsat data and GIS technique to assess the impacts of LULC on LST over the last 19 years in the Nile Delta of Egypt. Jiang and Tian (2010) applied the temperature-vegetation index (HVX) to explore the action of land changes on LST. Hathway and Sharples (2012) examined the influence of water bodies on decreasing the impact of Urban Heat Island in the UK. Ogashawara and Bastos (2012) studied the relationship between urban areas, water bodies, and LST of Brazilian urban areas using Landsat TM images. Cai et al. (2016) used Landsat TM/ ETM+ images to quantify the impacts of LULC pattern changes on LST in Fuzhou City, China. Kumar et al. (2018) used Landsat TM and Landsat TIRS/OLI images to assess the impacts of land cover changes on LST between 1990 and 2015 in Spiti Valley, India. Mustafa et al. (2019) used remote sensing indices and Landsat images to estimate the effects of land use dynamics on Beijing's microclimate from 1997 to 2017. Hussain et al. (2019) applied remote sensing and GIS tools to investigate changes in LULC patterns and their impacts on LST over 40 years in Lodhran District, Pakistan.

Egypt's historical susceptibility to climate change alters remarkably with the accomplishment of the Aswan High Dam (Yates and Strzepek 1998). The Aswan High Dam was built in 1964 to afford the overflow of the Nile River. In 1990, the dam approached its highest storage capacity (178 m above sea level), and the Egyptian government intended to redirect water to the Toshka Valley (Sparavigna 2012). At the end of 1990, water began to flow from the Nile River through Sadat Canal by a pumping station, supplying water to the depressions and forming four large lakes. In late 1998, the first giant lake grew far east, after which other successive lakes grew west from 2000 to 2001 (El Bastawesy et al. 2007). The Egyptian government confirmed to undertake a new project recognized as the "New Valley Project." This project aimed to move the population out of the Nile Valley and Delta into the desert by reclaiming new agricultural lands and enhancing infrastructure and industrial development. In 2006, evaporation began to reduce lakes as water supply from the Nile declined due to economic obstacles and the emergence of technical and environmental problems (El-Shabrawy and Dumont 2009). By 2012, the lowest portions of the main basins were filled with about 80\% less water than in 2002 (Omran and Negm 2020). Salt crusts were then formed above the evaporated portions of the lakes (Sparavigna 2011). These crusts can affect microbial activity and soil chemical and 
physical properties, thus reducing soil productivity and plant growth due to salt toxicity and intensified soil degradation (Amini et al. 2016). Most of the uncertainty about the Toshka project is due to the lack of itemized planning for all parts of establishment and development and the lack of information on the environmental impacts of this project. Lonergan and Wolf (2001) reported that the Toshka project had a tremendous impact on the Egyptian environment. They showed that upstream salinity and pollutants resulted in the loss of extra agricultural lands and significantly affected the Nile Delta environment. El Bastawesy et al. (2007) predicted that the rate of water loss from the Toshka Depression was approximately $2.5 \mathrm{~m} / \mathrm{y}$, and the water stored in the lake reduced to about 12.57 billion $\mathrm{m}^{3}$ in 2006. Baradei and Al Sadeq (2019) utilized three models to estimate the evaporation rate in Toshka. They reported that the average evaporation rate in the study area ranged from 7.92 to $8.09 \mathrm{~mm} / \mathrm{day}$. Mostafa et al. (2019) have predicted that by 2090 , Aswan's maximum temperature will rise by about $5.6 \pm 0.5^{\circ} \mathrm{C}$ compared to $2006-2015$. El-Marsafawy et al. (2018) reported that Egypt is characterized by an arid climate with an evaporation rate ranged from 1500 to $2400 \mathrm{~mm} / \mathrm{y}$. In addition, the meteorological data managed by the Aswan Dam Authority (HADA) shows that the highest evaporation rate in this region was about $7.8 \mathrm{~mm} /$ day in 2010 (Hassan et al. 2018). Vardavas and Fountoulakis (1996) developed a model to estimate the rate of evaporation from lakes. They have shown that the rate of radiation absorbed by water is responsible for the rise in water temperature during the summer. However, the absorbed energy is ready to evaporate and lose water temperature in winter. Bayoumi and Abu-Zeid (2001) characterized the negative influences of the Toshka Lakes. They reported that the lakes were subject to higher evaporation rates and could ultimately turn into salt crusts. Previous studies have not assessed the degree of soil degradation caused by the formation of these crusts due to evaporation.

Surface waters play a considerable role in mitigating the impacts of global warming and supporting climate adaptation. Surface water features create urban cool islands to mitigate the effects of urban heat islands (Gupta et al. 2018). Water bodies are recognized as high radiation absorbers and have a favorable influence on cooling the surrounding environment (Khan et al. 2019). Air temperature rise is considered the main factor in changing the surface water temperature of lakes and heat flux imbalance (Czernecki and Ptak 2018). There is no doubt that the drying of the Toshka Lakes due to evaporation increases intense warming in the surrounding area. The limitations of previous studies related to the impacts of changes in LULC on microclimate and environment were investigated, especially in the present study area. In this research, we used remote sensing and GIS to investigate the effects of LULC in the Toshka region from the drying of lakes on LST. Furthermore, the results are seen as the beginning of a detailed study on further reduction of environmental degradation due to anthropogenic changes.

\section{Study area}

The Toshka Depression is located almost $250 \mathrm{~km}$ south of the Aswan High Dam (179 m a.s.1.), between $22^{\circ} 50^{\prime} 0^{\prime \prime} \mathrm{N}$ to $23^{\circ} 30^{\prime} 0^{\prime \prime} \mathrm{N}$ and $30^{\circ} 10^{\prime} 0^{\prime \prime} \mathrm{E}$ to $31^{\circ} 20^{\prime} 0^{\prime \prime} \mathrm{E}$ (Fig. 1). It consists of four sub-depressions connected by natural is located at $150 \mathrm{~m}$ a.s.l. (Hamdan et al. 2016). The research area is mainly enveloped by sedimentary rocks. The Toshka region is part of the western desert of Egypt, which is considered one of the driest regions in Egypt. It has 
undergone alternative climatic conditions that have affected the characteristics of the current terrains. The area is characterized by arid climatic conditions with limited yearly rainfalls. Annual precipitation is about $1 \mathrm{~mm} / \mathrm{y}$. The Toshka Depression is located in a hyper-arid zone, and the evaporation rate in this region proceeds toward $5.9 \mathrm{~mm} /$ day (Chipman, 2019). The average temperature fluctuates from $16^{\circ} \mathrm{C}$ in the winter season to $35^{\circ} \mathrm{C}$ in the summer season. The depression is characterized by a flat surface on its eastern side and sand dunes and low hills on its western side. The Toshka region is distinguished by an enormous accumulation of sand dunes and is mostly influenced by the intense winds that control the dunes in the Sahara Desert (Elbasiouny and Elbehiry 2019).The study area is characterized by basement rocks surmounted by sedimentary successions. The sedimentary rocks are identified by the Paleozoic and Cenozoic rocks, while the basement rocks are covered by granites, gneiss, and granodiorite (Abdel Moneim et al. 2014). Many geomorphologic units are displayed in this area, including alluvial plains, depressions, sandy and erosional plains, and hilly regions (Alfaran, 2013). The development of this plain is under the control of a progression series of faults and folds (Hamdan et al., 2016). The soil temperature regime of the Toshka region is classified as hyperthermic, and the soil moisture regime is considered aridic (torric) (USDA 2014).

\section{Materials and methods}

\section{Satellite images}

As a way to predict changes in LULC and LST due to the disappearance of Toshka Lakes, 12 images of Landsat-5 TM between July 2001 and July 2009, and 6 images of Landsat-8 (OLI/TIRS) from July 2013 to July 2019 (paths 175\&176/rows 44) were obtained from Earth Explorer (https://earthexplorer.usgs.gov/). All images consist of thermal bands (band 6 for ETM+ with a spatial resolution of $60 \mathrm{~m}$ and band 10 for OLI with a spatial resolution of $100 \mathrm{~m}$ ). To reduce the atmospheric effects, the FLAASH Module was utilized in ENVI 5.3 (Perkins et al. 2005), and the mosaic tool was applied in ArcMap 10.5.

\section{Image processing}

The Automated Water Extraction Index (AWEI) introduced by Feyisa et al. (2013) was applied to the mosaicked by positive values, and other bodies are symbolized by negative values. A threshold value was adjusted to extract water pixels from other land cover classes (-0.28). Pixels higher than the threshold value are considered water bodies.

For Landsat ETM+, the proposed mathematical index is calculated according to Equation 1:

$A W E I=\rho_{\text {band } 1}+2.5 \times \rho_{\text {band } 2}-1.5 \times\left(\rho_{\text {band } 4+} \rho_{\text {band } 5}\right)-0.25 \times \rho_{\text {band } 7}(1)$

where $\rho$ represents the reflectance values of the Landsat ETM+ bands

167 For Landsat OLI, the proposed mathematical index is calculated according to Equation 2:

$A W E I=\rho_{\text {band } 2}+2.5 \times \rho_{\text {band } 3}-1.5 \times\left(\rho_{\text {band } 5+} \rho_{\text {band } 6}\right)-0.25 \times \rho_{\text {band } 7}(2)$

where $\rho$ represent the reflectance values of Landsat OLI bands 
After using the AWEI index, the target water area was estimated from 2001 to 2019. Landsat-8 OLI images obtained in July 2019 were utilized to recognize the reclaimed area in the Toshka project. The Optimized Soil-Adjusted Vegetation Index" (OSAVI), introduced by Rondeaux et al. (1996), was utilized to detect the reclaimed zone in the project by applying a threshold value of 0.2 and is estimated as by Equation 3 :

OSAVI $=\left(\rho_{\text {nir- }} \rho_{r) /}\left(\rho_{\text {nir }+} \rho_{r+} 0.16\right)(3)\right.$

where $\rho_{\text {nir }}$ and $\rho_{r}$ are the reflectance values of near-infrared and red bands, respectively. Soil adjustment coefficient (0.16) was chosen as a favorable value to diminish deviation with the soil background influence (Rondeaux et al. 1996). OSAVI outperforms NDVI as OSAVI and is formulated to diminish the sensitivity of NDVI to soil brightness effect (Steven 1998). Feyisa et al. (2013) concluded that this index has an advantage in extracting water bodies in areas with high environmental noise where other extraction indices fail to extract correctly. Arshad et al. (2020) declared that the SAVI index is preferable to use in regions with relatively barren vegetation. In addition, Mokarram et al. (2015) reported that OSAVI was derived as a modulation of the NDVI index to reduce the effect of soil brightness in areas with sparse vegetation.

For Landsat-5 TM images, the LST of the research area was calculated using the formula established by the Landsat Project Science Office (2002). Digital number (DN) was converted to spectral radiance (L) using Equation 4:

$$
L \lambda=\left(L_{M A X}-L_{M I N}\right) / 255 \times D N+L_{M I N},(4)
$$

where $L_{M A X}, L_{M I N}$ are the spectral radiance of the $\mathrm{DN}$ value.

For Landsat-8 OLI images, the LST of the research area was estimated using NASA procedures on the thermal bands of Landsat images obtained in 2019. Top of Atmosphere spectral radiance $L \lambda$ is retrieved by Equation 5 (Barsi et al. 2014):

$$
L \lambda=M_{L \times} \mathcal{Q}_{\mathrm{cal}+} A_{L},(\mathbf{5})
$$

where $M_{L}$ is a band-specific multiplicative rescaling factor from the metadata file $\mathcal{Q}_{\text {cal }}$ that corresponds to the thermal band, and $A_{L}$ is a band-specific additive rescaling factor from the metadata file.

For Landsat TM and Landsat OLI images, DNs were converted to reflection. The spectral radiance is converted to brightness temperature (BT) in Celsius by Equation 6 (Avdan and Jovanovska 2016):

$$
\mathrm{BT}=\frac{K_{2}}{\ln \left[\left(K_{1} / L \lambda\right)+1\right]}-273.15(\mathbf{6})
$$

where $K_{1}$ and $K_{2}$ are band-specific thermal conversion constants from the metadata file. A regression model was used to plot the correlation between LST and the area of Toshka Lakes in MS Excel.

\section{Reference data}

The high spatial resolution images provided by Google Earth ${ }^{\mathrm{TM}}$ and Landsat (NIR) bands were used as a reference to distinguish between water pixels from non-water features. The selection of NIR band is because of its great ability to differentiate water features from other land cover areas. The date of the Landsat imagery and the reference data matched. A confusion matrix was created to quantify the accuracy of the AWEI index. The matrix contains values for overall accuracy, user's accuracy, producer's accuracy, Kappa coefficient, Omission Error, and Commission Error. 


\section{LST validation}

207 The estimated land surface temperature is compared with the actual air temperature data from meteorological stations to validate LST ( $\mathrm{Li}$ et al. 2013; Mukherjee and Singh 2020). In this research, the LST values estimated from satellite images were validated by comparing them with the actual air temperature values measured simultaneously and derived from the Aswan Station 624140 (HESN). A flow chart of methodology is displayed in Fig. 2.

\section{Results and discussion}

212 By applying the AWEI to retrieve the surface area of Toshka Lakes, the results demonstrated that the total surface 213 area of the four Toshka Lakes was about $1587.71 \mathrm{~km}^{2}$ in 2001 . By 2009, the surface area of the lakes reduced to about $214585.98 \mathrm{~km}^{2}$ due to evaporation. In 2019, only one lake was left with an area of $69.92 \mathrm{~km}^{2}$ (Table 1 and Fig. 3). The 215 total shrinking of the lakes was $1517.79 \mathrm{~km}^{2}$ between 2001 and 2019. Significant water loss in lakes can be related to evaporation, while limited amounts percolated into groundwater. Percolation into groundwater may be disregarded as

217 the bedrock in the area is formed by a thick impermeable clayey layer (Fassieh and Zaki 2013). The drying parts of 218 these human-induced lakes are converted to bare soil and covered with salt crusts. These crusts alter the physicochemical characteristics of the soil and pose tremendous environmental hazards. These effects include reduced plant water availability and soil organic matter content, plant dehydration, limited plant growth, and soil productivity, leading to soil degradation. Salt crusts can alter the environmental conditions of microorganisms and reduce the rate of organic matter decomposition in soil. These crusts are expected to reduce soil evaporation rate by covering the topsoil surface and increasing albedo, which resists moisture transfer from the soil surface. The accumulation of salts on the soil surface can also cause plant dehydration by reducing the osmotic potential and water availability to soil plants. In addition to plant dehydration, these crusts can damage the soil structure by disturbing soil aggregates. Salts affect crop production by reducing the nutrients uptake and restricting plant growth and reproduction. Compared to other studies, Chipman and Lillesand (2007) estimated that the total area of Toshka Lakes increased to $1740 \mathrm{~km}^{2}$ by 2001 but diminished to $900 \mathrm{~km}^{2}$ by 2006 . In this research, AWEI index performs a good technique in the extraction of water features. The overall accuracy ranges from $93 \%$ to $99 \%$ during the study period. The Kappa coefficient ranges from $85.6 \%$ to $97.2 \%$, which is in a high agreement with the reality (Table 2). The visual interpretation using high spatial resolution images supplied by Google Earth shows that the true boundaries of lakes coincide very closely the extracted boundaries using AWEI index. However, some omissions were found that led to errors in the results. The accuracy of this technique is influenced by many factors including sun angle, atmospheric condition, atmospheric correction technique, and water features properties (Feyisa et al. 2013).

The land surface temperature (LST) was estimated from Landsat images between 2001 and 2019 to address the impacts of Toshka Lakes dryness on the environment. The results clarified that the average LST was about $23.39^{\circ} \mathrm{C}$ in July 2001. By July 2009 , the average LST of this region increased to $42.34^{\circ} \mathrm{C}$, while in July 2019 , the average LST rose to approximately $48.41^{\circ} \mathrm{C}\left(0.6^{\circ} \mathrm{C} / \mathrm{y}\right)$ (Figs. 4 and 5). This rise in temperature is due to the conversion of evaporated areas of lakes to bare soil covered with salt crusts. The rareness of precipitation in this arid environment may illustrate this rising in LST values. In comparison with water features, bare soil reflects the greatest rate of radiance flux and this explains the elevated values of temperature in the images (Carrasco et al. 2020). The actual air temperature was 
obtained from Aswan Station 624140 (HESN) to validate the LST. Table 3 displays the average air temperatures for

244 LST from Landsat data and Aswan Station. Based on Aswan Station data, the highest mean temperature in July 2019 was $38.1^{\circ} \mathrm{C}$, and the lowest mean temperature in July 2001 was $34.4^{\circ} \mathrm{C}$. Validation of LST estimated from Landsat images against recorded at Aswan station is shown in Table 4. A negative variation indicates that the LST estimated from Landsat images is higher than the Aswan Station air temperature. In contrast, a positive variation indicates that the estimated LST is lower than the station temperature. The maximum deviation for all estimated LST datasets in July 2017 was approximately $-11.7^{\circ} \mathrm{C}$. The minimum deviation for all estimated LSTs was $1.82^{\circ} \mathrm{C}$ that occurred in July 2005. This may be due in part to cloud coverage. In addition, the recorded data is not pertinent to the entire region, but only to specific regions where the meteorological stations are available. Therefore, it is difficult to obtain "correct" temperature data for the entire region.

The regression analysis showed a strong negative correlation between LST and the area of Toshka Lakes (R-square was about 0.98) (Fig. 6). Pal and Ziaul (2017) showed a negative correlation between the ratio of water bodies and average LST. . In spite of the fact that a certain part of LST change can be related to external climate change conditions, the results indicated that human-induced changes in land cover create considerable involvements on LST variation.

Although Toshka Lakes were formed in recent years by diverting water from Lake Nasser, the drying of these lakes had serious impacts on the microclimate of this region. This study estimates that the temperature has risen by about $6.07^{\circ} \mathrm{C}$ over the last decade, signaling a growing concern about global warming rates in the region. It is predicted that the temperature has increased by about $0.6^{\circ} \mathrm{C} / \mathrm{y}$ between 2009 and 2019. Our findings comply with Hereher (2017), who estimated that LST increased by about $0.4^{\circ} \mathrm{C} / \mathrm{y}$ from 2003 to 2015 in the same study area. The difference in LST estimation was associated with many factors, including seasonal variation, land cover change, different study periods, climate change, and the resolution of satellite images. This study revealed that the dried parts of the lakes had a higher LST than areas which are covered with water before evaporation with lower temperatures. Global warming has many adverse impacts on the environment.

High temperatures increase soil evapotranspiration, reduce the moisture content of the soil, and promote the rate of mechanical weathering. Temperature rise due to the disappearance of these lakes enhances salt accumulation in the soils in these arid regions, reduces organic matter, and stimulates soil erosion and degradation. Increasing temperature is expected to decrease soil carbon storage by enhancing the microbial decomposition of soil organic matter. Thus, if the decomposition rate of soil organic carbon is greater than the growth of plants in arid environments, the soil is a source of carbon dioxide in the atmosphere. High temperatures can reduce soil water content and decrease crop production. Biological activity is also influenced by the low moisture content of the soil. The frequency of windinduced soil erosion in arid regions probably increases due to climate change. In warmer climates, it is expected that the risk of wind erosion increases in arid and semi-arid environments because of the loss of biomass. Global warming can have serious consequences, especially in dry environments where precipitation is reduced, and evaporation rates are likely to increase, contributing to more drought conditions. In addition, high temperatures can affect biological systems by altering the adaptive capacity of many animal and plant species, thus increasing their risk of extinction. 
High temperatures are expected to influence the dispersal of infectious diseases and increase human health hazards. People in these dry areas can be affected by changes in the temperature regime in these areas. As surface temperatures continue to rise, people are more likely to migrate from hot regions where air-cooling systems are expensive. In such areas, the risk of diseases escalates and threatens their lives and work. Lozano-Parra et al. (2018) pointed out that soil vegetation cover and moisture content lower soil temperature in dry environments.

The Toshka project, which aimed to create new arable land in the western desert, ended due to failure to reach that goal and many environmental issues. The OSAVI index was used to estimate the total area of land reclaimed in Toshka by 2019. By applying this index (threshold 0.2), the total land reclaimed in 2019 was only 41,659 acres (Fig. 7).

287 Hereher (2014) detected that the total land reclaimed in Toshka by 2013 was approximately 30,000 acres by applying the SAVI index. This study estimated that by 2019, the land reclaimed in this project was $13 \%$ of the land that the Egyptian government aimed to reclaim by the Toshka project in 2017 (560,000 acres). A low supply of water and elevated temperatures reduce the vegetation density in the study area. A documented environmental impact assessment had to be conducted on-site before the project was launched. Assessing the potential impacts of a planned project on the environment helps define the achievability of the project. Improper planning of the Toshka project has caused innumerable environmental damage. The Toshka project must be treated as an existing reality. The mistakes made in it must be corrected and put back on the right path to achieve its goals.

\section{Conclusion}

This study uses Landsat TM/OLI images to investigate the effects of LULC changes on LST in the Toshka region. Current research addresses important issues by concretely analyzing human-induced changes and LST changes in one of Egypt's aridest environments. According to this study, the total area of Toshka Lakes decreased by about 1517.79 $\mathrm{km}^{2}$ from 2001 to 2019 . In this period, the LST increased consistently $\left(0.6^{\circ} \mathrm{C} / \mathrm{y}\right)$. The results revealed that LST rose significantly in the lake areas that were dried by evaporation. This represents a high correlation between the land use change caused by these artificial lakes and the LST. Due to the high surface temperature, the area is vulnerable to natural hazards, diseases, severe droughts, and reduced soil productivity. These areas have also been observed to be covered with salt crusts, which may increase the risk of desertification. More areas are expected to be susceptible to wind erosion due to LST. This can adversely affect the survival of various habitats for environmental balance. The author recommends expanding the vegetation cover in the Toshka region to reduce further increases in LST and control ecological damage. This paper focuses on the benefits of satellite data for estimating human-induced changes and their impacts on microclimate. This helps land management experts and policymakers manage newly reclaimed areas and make decisions that limit the impacts of human-induced changes on LST dynamics and the environment. Therefore,

\section{Declarations}

\section{Ethics approval and consent to participate}

313 Not applicable

\section{Consent for publication}


Not applicable

\section{Data availability}

317 The datasets supporting the conclusions of this article are included within the article

\section{Competing interests}

319 The author declares that she has no competing interests

320 Funding

321 The author received no financial support for the research, authorship, and/or publication of this article.

322 Authors' contributions

323 Rasha M. Abou Samra contributed to study conception and design, data collection, analysis and interpretation of results, draft manuscript preparation and to the approving of the final version of the manuscript.

\section{References}

Abd El-Hamid HT (2020) Geospatial Analyses for Assessing the Driving Forces of Land Use/Land Cover Dynamics Around the Nile Delta Branches, Egypt Journal of the Indian Society of Remote Sensing 48:1661-1674. https://doi.org/10.1007/s12524-020-01189-2

Abdel Moneim A, Zaki S, Diab M (2014) Groundwater conditions and the geo-environmental impacts of the recent development in the South Eastern part of the Western Desert of Egypt. J Water Resour Prot 6:381-401

Alfaran SMA (2013) Geologic and geomorphologic impacts on the water resources, Toshka area and its vicinities, South Western Desert, Egypt. PhD thesis, Ain Shams University, Cairo, p 152

Amini S, Ghadiri H, Chen C, Marschner P (2016) Salt-affected soils, reclamation, carbon dynamics, and biochar: a review Journal of Soils and Sediments 16:939-953 Contribution, Water International, 26:4, 589-596, DOI: $10.1080 / 02508060108686959$

Arshad M, Eid EM, Hasan M (2020) Mangrove health along the hyper-arid southern Red Sea coast of Saudi Arabia

Avdan U, Jovanovska G (2016) Algorithm for automated mapping of land surface temperature using LANDSAT 8 satellite data Journal of Sensors. https://doi.org/10.1155/2016/1480307.

Balew A, Korme T (2020) Monitoring land surface temperature in Bahir Dar city and its surrounding using Landsat images The Egyptian Journal of Remote Sensing and Space Science. https://doi.org/10.1016/j.ejrs.2020.02.001

Barsi JA, Schott JR, Hook SJ, Raqueno NG, Markham BL, Radocinski RG (2014) Landsat-8 thermal infrared sensor (TIRS) vicarious radiometric calibration Remote Sensing 6:11607-11626. https://doi.org/10.3390/rs61111607

Bayoumi M, Abu-Zeid K (2001) Environmental impact assessment of the south Egypt development project (Toshka project) Water Sciences 30: 10-18. 
Cai Y, Zhang H, Zheng P, Pan W (2016) Quantifying the impact of land use/land cover changes on the urban heat island: A case study of the natural wetlands distribution area of Fuzhou City, China Wetlands 36:285-298. https://doi.org/10.1007/s13157-016-0738-7

Carrasco RA, Pinheiro MMF, Junior JM, Cicerelli RE, Silva PA, Osco LP, Ramos APM (2020) Land use/land cover change dynamics and their effects on land surface temperature in the western region of the state of São Paulo, Brazil Regional Environmental Change 20:1-12

Chipman J, Lillesand T (2007) Satellite-based assessment of the dynamics of new lakes in southern Egypt International Journal of Remote Sensing 28:4365-4379. https://doi.org/10.1080/01431160701241787

Chipman JW (2019) A multisensor approach to satellite monitoring of trends in lake area, water level, and volume Remote Sensing 11:158. https://doi.org/10.3390/rs11020158

Czernecki B, Ptak M (2018) Impact of global warming on lake surface water temperature in Poland-the application of empirical-statistical downscaling, 1971-2100 Journal of Limnology

El Baradei S, Al Sadeq M (2019) Optimum coverage of irrigation canals to minimize evaporation and maximize dissolved oxygen concentration: case study of Toshka, Egypt International Journal of Environmental Science and Technology 16:4223-4230. https://doi.org/10.1007/s13762-018-2010-6

El Bastawesy M, Arafat S, Khalaf F Estimation of water loss from Toshka Lakes using remote sensing and GIS. In: 10th AGILE International Conference on Geographic Information Science. Aalborg University, Denmark, 2007. pp 1-9 Elbasiouny H., Elbehiry F. (2019).

El-Beltagy A, Madkour M (2012) Impact of climate change on arid lands agriculture Agriculture \& Food Security $1: 3$

El-Marsafawy S., Bakr N., Elbana T., El-Ramady H. (2019) Climate. In: El-Ramady H., Alshaal T., Bakr N., Elbana T., Mohamed E., Belal AA. (eds) The Soils of Egypt. World Soils Book Series. Springer, Cham. https://doi.org/10.1007/978-3-319-95516-2_5

El-Shabrawy GM, Dumont HJ (2009) The Toshka Lakes. In: The Nile. Springer, pp 157-162.https://doi.org/ 10.1007/978-1-4020-9726-3_8

Fassieh KM, Zaki MA (2014) A water management model for Toshka depression Journal of Applied Mathematics 2014: 1-9. https://doi.org/10.1155/2014/731846

Feizizadeh B, Blaschke T (2012) Thermal Remote Sensing for Land Surface Temperature Monitoring: Maraqeh County, Iran. In: international geoscience and remote sensing symposium, 2012. Proceedings. https://doi.org/10.1109/IGARSS.2012.6350808

Feyisa GL, Meilby H, Fensholt R, Proud SR (2014) Automated Water Extraction Index: A new technique for surface water mapping using Landsat imagery Remote Sensing of Environment 140:23-35. https://doi.org/10.1016/j.rse.2013.08.029 
Gupta N, Mathew A, Khandelwal S (2019) Analysis of cooling effect of water bodies on land surface temperature in nearby region: a case study of Ahmedabad and Chandigarh cities in India The Egyptian Journal of Remote Sensing and Space Science 22:81-93

Hamdan M, Refaat A, Wahed MA (2016) Morphologic characteristics and migration rate assessment of barchan dunes in the Southeastern Western Desert of Egypt Geomorphology 257:57-74 https://doi.org/10.1016/j.geomorph.2015.12.026

Hamdan MA, Refaat AA, Abdel Wahed M (2016) Morphologic characteristics and migration rate assessment of barchan dunes in the Southeastern Western Desert of Egypt. Geomorphology 257, 57-74, doi:10.1016/j.geomorph.2015.12.026

Hassan A, Ismail SS, Elmoustafa A, Khalaf S (2018) Evaluating evaporation rate from high Aswan Dam Reservoir using RS and GIS techniques The Egyptian Journal of Remote Sensing and Space Science 21:285-293. https://doi.org/10.1016/j.ejrs.2017.10.001

Hathway E, Sharples S (2012) The interaction of rivers and urban form in mitigating the Urban Heat Island effect: A UK case study Building and Environment 58:14-22

Hereher ME (2015) Environmental monitoring and change assessment of Toshka lakes in southern Egypt using remote sensing Environmental Earth Sciences 73:3623-3632

Hereher ME (2017) Effects of land use/cover change on regional land surface temperatures: severe warming from drying Toshka lakes, the Western Desert of Egypt Natural Hazards 88:1789-1803. https://doi.org/10.1007/s11069-017-2946-8

Hooker J, Duveiller G, Cescatti A (2018) A global dataset of air temperature derived from satellite remote sensing and weather stations Scientific data 5:1-11. https://doi.org/10.1038/sdata.2018.246

Hussain S et al. (2019) Using GIS tools to detect the land use/land cover changes during forty years in Lodhran District of Pakistan Environmental Science and Pollution Research: 1-17. https://doi.org/10.1007/s11356$\underline{019-06072-3}$

Jiang J, Tian G (2010) Analysis of the impact of land use/land cover change on land surface temperature with remote sensing Procedia environmental sciences 2:571-575

Jingyong Z, Wenjie D, Lingyun W, Jiangfeng W, Peiyan C, Lee D-K (2005) Impact of land use changes on surface warming in China Advances in Atmospheric Sciences 22:343-348. https://doi.org/10.1007/BF02918748

Khan N, Shahid S, Chung E-S, Kim S, Ali R (2019) Influence of surface water bodies on the land surface temperature of Bangladesh Sustainability 11:6754

Kumar P, Husain A, Singh RB, Kumar M (2018) Impact of land cover change on land surface temperature: A case study of Spiti Valley Journal of Mountain Science 15:1658-1670. https://doi.org/10.1007/s11629-018-4902$\underline{9}$ 
Lambin EF (1997) Modelling and monitoring land-cover change processes in tropical regions Progress in physical geography 21:375-393. https://doi.org/10.1177/030913339702100303

Landsat Project Science Office

(2002) Landsat 7 Science

Data User's Handbook. URL: http://tpwww.gsfc.nasa.gov/IAS/handbook/handbook_toc. html, Goddard Space Flight Center, NASA, Washington, DC (last date accessed: 10 September 2003).

Li J-j, Wang X-r, Wang X-j, Ma W-c, Zhang H (2009) Remote sensing evaluation of urban heat island and its spatial pattern of the Shanghai metropolitan area, China Ecological Complexity 6:413-420. https://doi.org/10.1016/j.ecocom.2009.02.002

Li Z-L, Tang B-H, Wu H et al (2013) Satellite-derived land surface temperature: current status and perspectives. Remote Sens Envi- ron 131:14-37

Li ZL, Tang BH, Wu H, Ren HZ, Yan GJ, Wan ZM, Trigo IF, Sobrino JA (2013) Satellite-derived land surface temperature: Current status and perspectives Remote Sensing of Environment 131:14-37. https://doi.org/10.1016/j.rse.2012.12.008

Lonergan S, Wolf A (2001) Moving Water to Move People The Toshka Project in Egypt A Water Forum

Lozano-Parra J, Pulido M, Lozano-Fondón C, Schnabel S (2018) How do soil moisture and vegetation covers influence soil temperature in drylands of Mediterranean Regions? Water 10:1747. https://doi.org/10.3390/w10121747

Mendelsohn R, Kurukulasuriya P, Basist A, Kogan F, Williams C (2007) Climate analysis with satellite versus weather station data Climatic Change 81:71-83. https://doi.org/10.1007/s10584-006-9139-x

Mokarram M, Hojjati M, Roshan G, Negahban S (2015) Modeling the behavior of Vegetation Indices in the salt dome of Korsia in North-East of Darab, Fars, Iran Modeling Earth Systems and Environment 1:27. https://doi.org/10.1007/s40808-015-0029-y

Mostafa AN, Wheida A, El Nazer M, Adel M, El Leithy L, Siour G, Coman A, Borbon A, Magdy AW, Omar M , Saad-Hussein A , Alfaro S (2019) Past (1950-2017) and future (-2100) temperature and precipitation trends in Egypt Weather and Climate Extremes 26:100225. https://doi.org/10.1016/j.wace.2019.100225

Mukherjee F, Singh D (2020) Assessing Land Use-Land Cover Change and Its Impact on Land Surface Temperature Using LANDSAT Data: A Comparison of Two Urban Areas in India Earth Systems and Environment: 1-23

Mustafa EK, Liu G, Abd El-Hamid HT, Kaloop MR (2019) Simulation of land use dynamics and impact on land surface temperature using satellite data GeoJournal:1-19. https://doi.org/10.1007/s10708-019-10115-0

Ogashawara I, Bastos VdSB (2012) A quantitative approach for analyzing the relationship between urban heat islands and land cover Remote Sensing 4:3596-3618

Omran E-SE, Negm AM (2020) Egypt's Environment from Satellite. In: Environmental Remote Sensing in Egypt. Springer, pp 23-91. https://doi.org/10.1007/978-3-030-39593-3_3 
Orhan O, Ekercin S, Dadaser-Celik F (2014) Use of landsat land surface temperature and vegetation indices for monitoring drought in the Salt Lake Basin Area, Turkey The Scientific World Journal 2014. https://doi.org/10.1155/2014/142939

Owen T, Carlson T, Gillies R (1998) An assessment of satellite remotely-sensed land cover parameters in quantitatively describing the climatic effect of urbanization International Journal of Remote Sensing 19:1663-1681. https://doi.org/10.1080/014311698215171

Pal S, Ziaul S (2017) Detection of land use and land cover change and land surface temperature in English Bazar urban centre The Egyptian Journal of Remote Sensing and Space Science 20:125-145. https://doi.org/10.1016/j.ejrs.2016.11.003

Perkins T, Adler-Golden S, Matthew M, Berk A, Anderson G, Gardner J, Felde G Retrieval of atmospheric properties from hyper and multispectral imagery with the FLAASH atmospheric correction algorithm. In: Remote Sensing of Clouds and the Atmosphere X, 2005. International Society for Optics and Photonics, p 59790E. https://doi.org/10.1117/12.626526

Pu R, Gong P, Michishita R, Sasagawa T (2006) Assessment of multi-resolution and multi-sensor data for urban surface temperature retrieval Remote Sensing of Environment 104:211-225. https://doi.org/10.1016/j.rse.2005.09.022

Rondeaux G, Steven M, Baret F (1996) Optimization of soil-adjusted vegetation indices Remote Sensing of Environment 55:95-107. https://doi.org/10.1016/0034-4257(95)00186-7

Sinha S, Sharma LK, Nathawat MS (2015) Improved land-use/land-cover classification of semi-arid deciduous forest landscape using thermal remote sensing The Egyptian Journal of Remote Sensing and Space Science 18:217-233. https://doi.org/10.1016/j.ejrs.2015.09.005

Sparavigna AC (2011) The decreasing level of Toshka Lakes seen from space arXiv preprint arXiv:11074430.

Sparavigna AC (2013) The Shrinking Toshka Lakes in the Google Earth Images International Journal of Sciences 2: 92-94.

Steven MD (1998) The sensitivity of the OSAVI vegetation index to observational parameters Remote Sensing of Environment 63:49-60. https://doi.org/10.1016/S0034-4257(97)00114-4

USDA (2014) Keys to Soil Taxonomy, 12 th ed. United States Department of Agriculture, Natural Resources Conservation Service (NRCS).

Vardavas IM, Fountoulakis A (1996) Estimation of lake evaporation from standard meteorological measurements: application to four Australian lakes in different climatic regions Ecological modelling 84:139-150. https://doi.org/10.1016/0304-3800(94)00126-X

Yates DN, Strzepek KM (1998) An assessment of integrated climate change impacts on the agricultural economy of Egypt Climatic Change 38:261-287. https://doi.org/10.1023/A:1005364515266 
481 Yu Y, Yu P (2020) Land Surface Temperature Product from the GOES-R Series. In: The GOES-R Series. Elsevier, pp 133-144. https://doi.org/10.1016/B978-0-12-814327-8.00012-3

483 Zhou X, WANG YC (2011) Dynamics of Land Surface Temperature in Response to Land-Use/Cover Change $484 \quad$ Geographical Research 49:23-36. https://doi.org/10.1111/j.1745-5871.2010.00686.x 


\section{Figures}

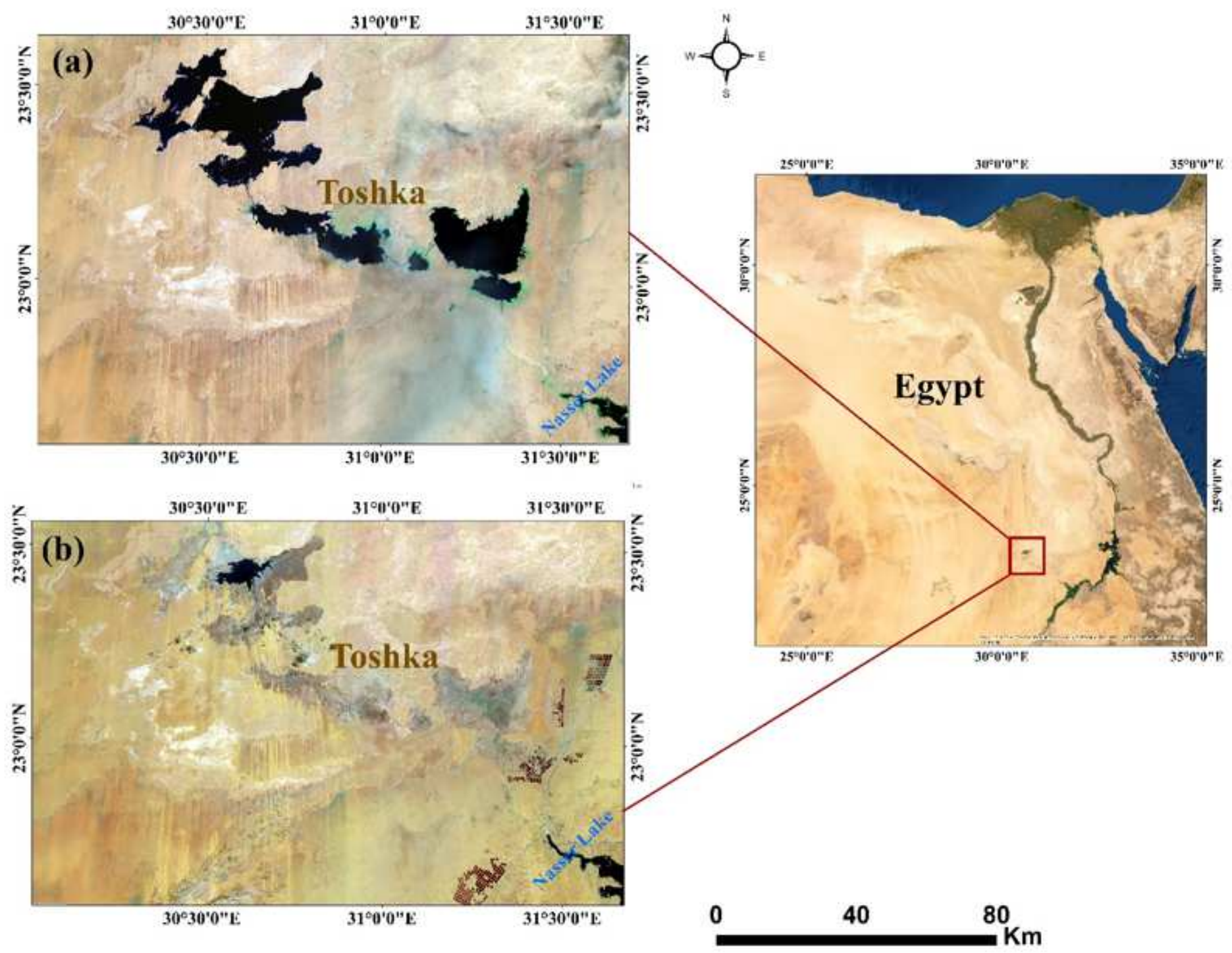

Figure 1

Location of the study area (a) using Landsat TM image (742) acquired on July 2001 (b) using Landsat OLI image (742) acquired on July 2019, brown dots in the south eastern corner are represented the reclaimed lands in the study area until 2019 


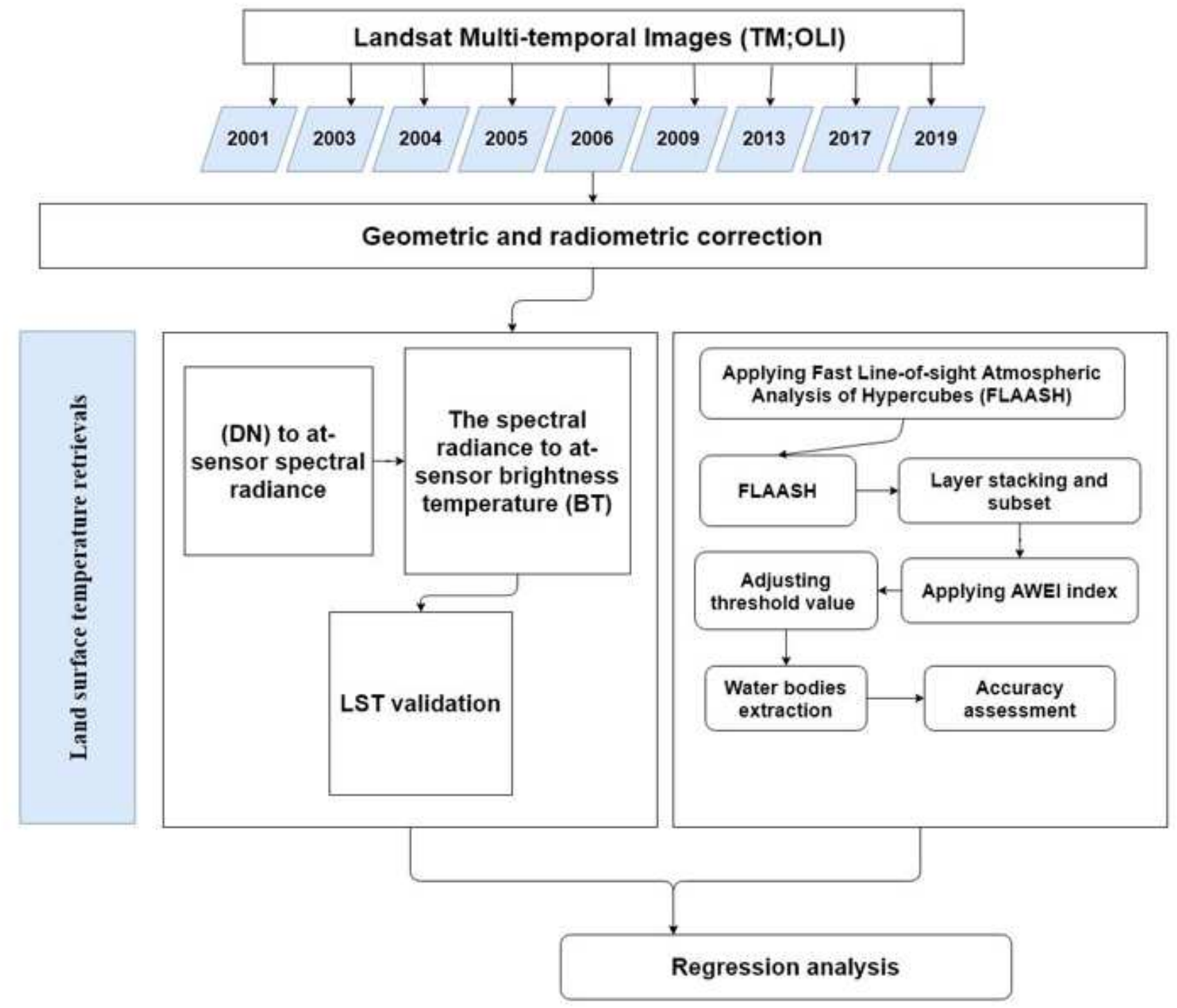

Figure 2

Flow chart of methodology showing the steps used in this work 


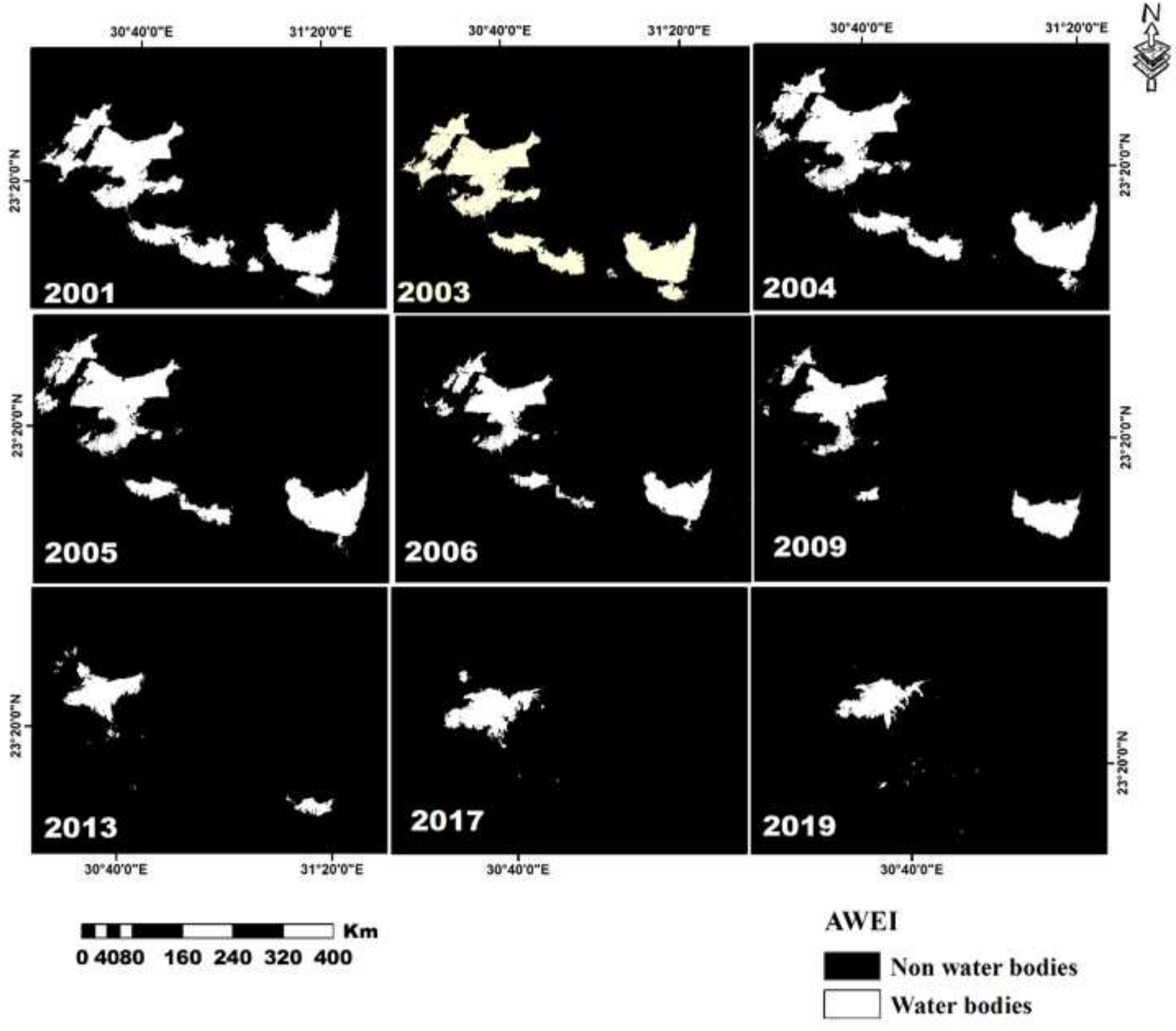

Figure 3

Comparison of area of Toshka lakes extracted from AWEl index between 2001 and 2019 


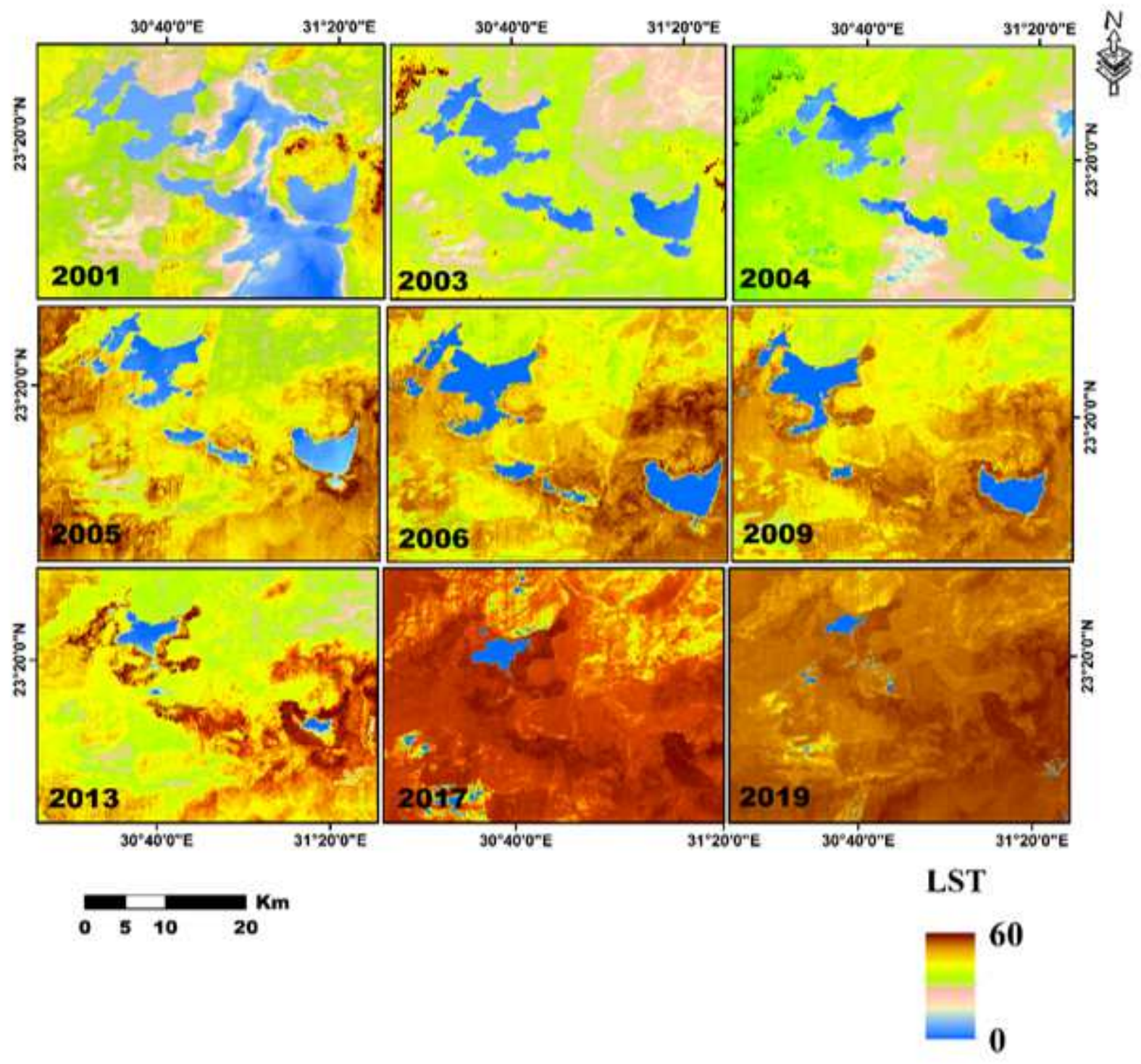

Figure 4

Comparison of LST of Toshka lakes between 2001 and 2019. Note that higher LST are detected in the drying areas of lakes which are converted to bare soil by evaporation 


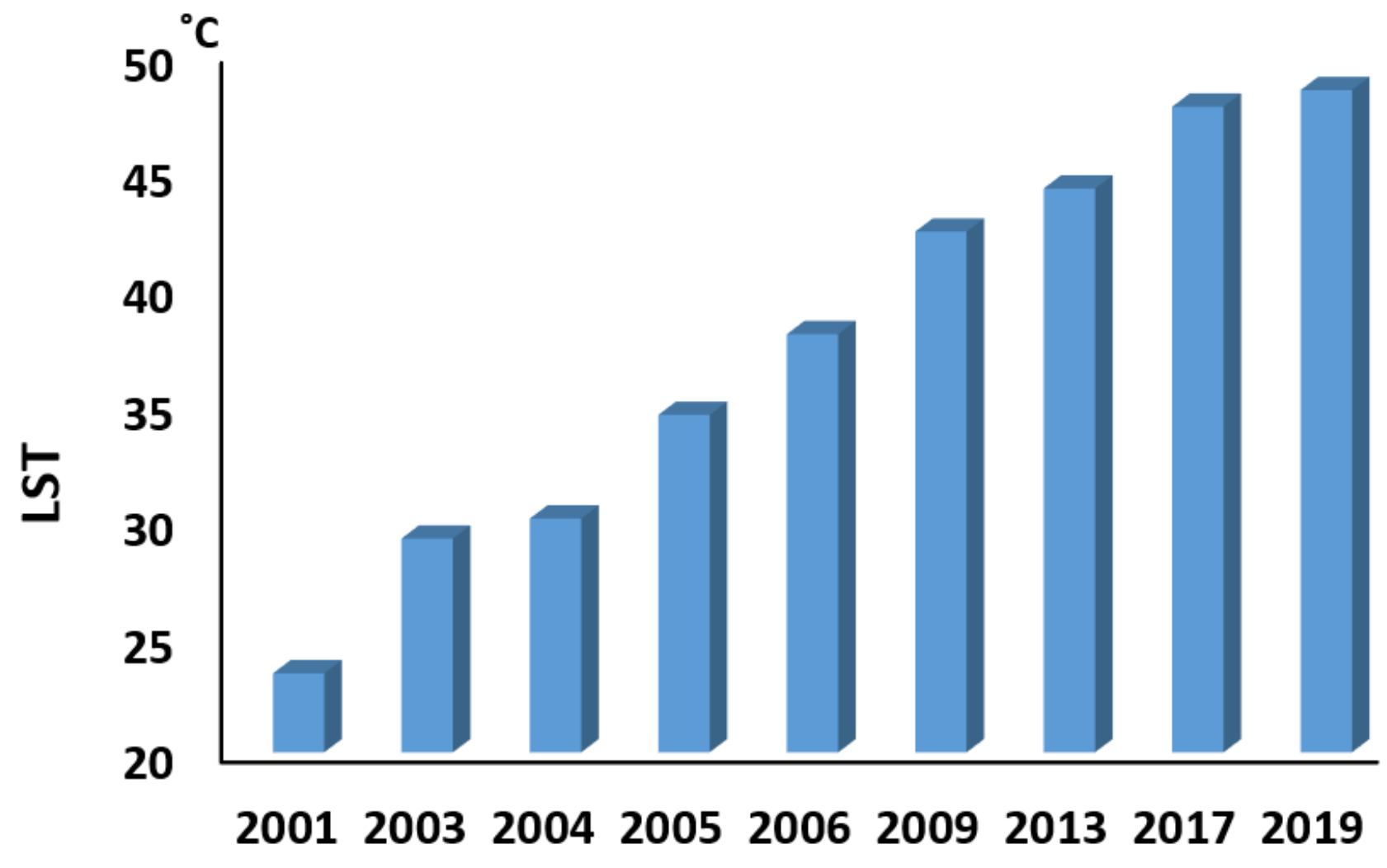

Figure 5

LST change of Toshka region between 2001 and 2019 


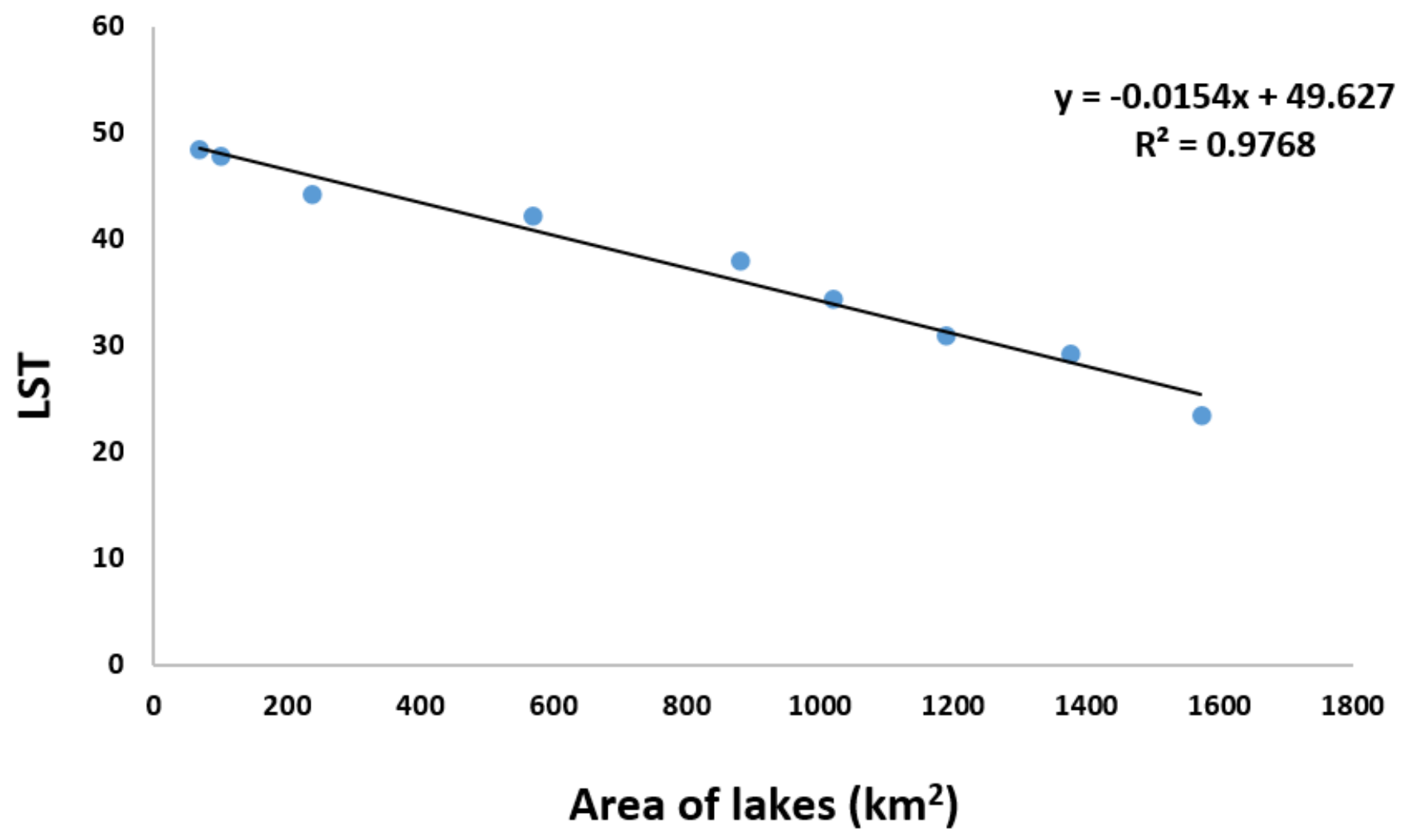

Figure 6

Regression plot between area of Toshka lakes and LST from 2001 to 2019 


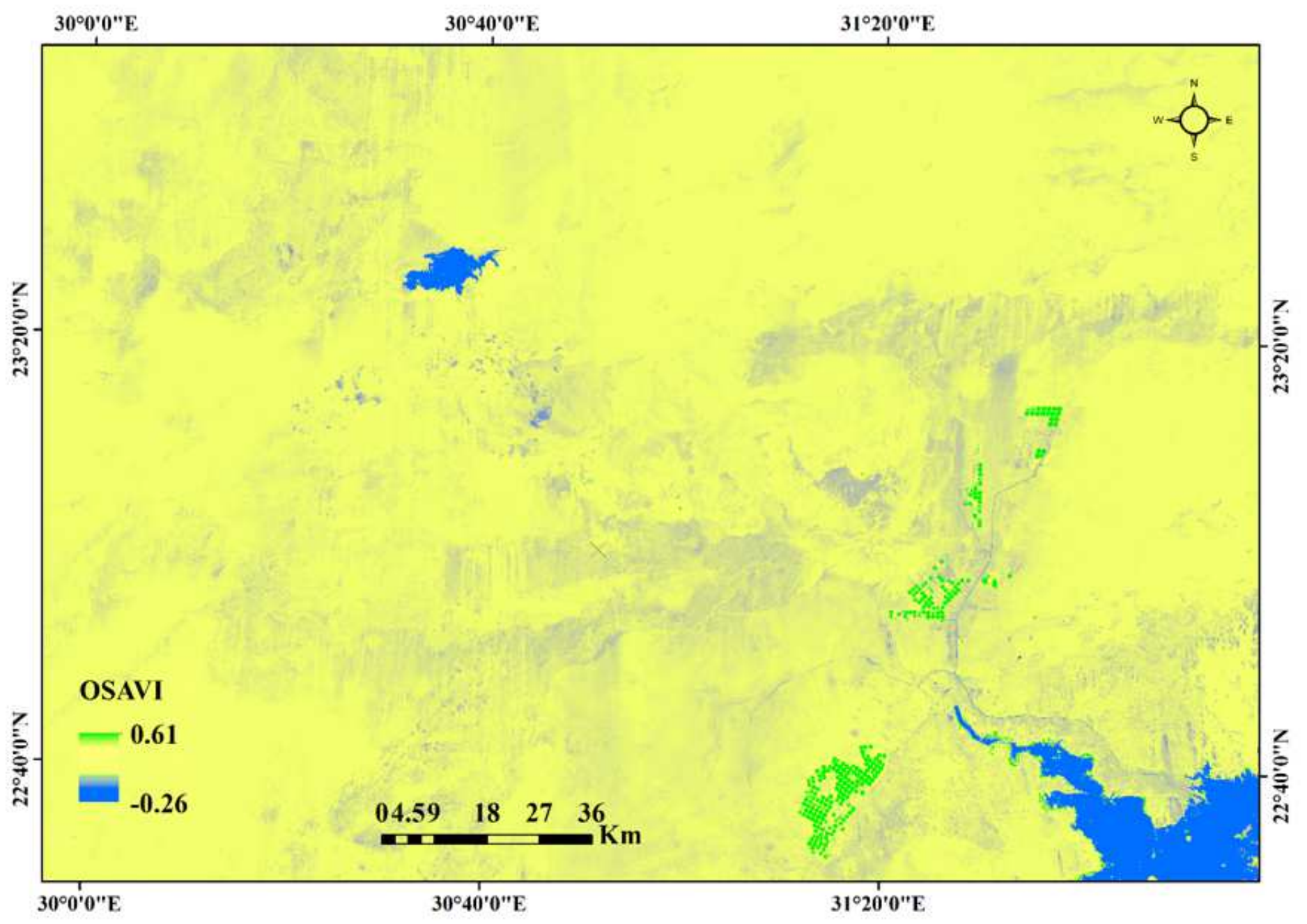

Figure 7

OSAVI image of Landsat OLI 2019 for Toshka region. Note that irrigated vegetation is represented by green color

\section{Supplementary Files}

This is a list of supplementary files associated with this preprint. Click to download.

- Tables.pdf 